\title{
Haematological and Biochemical Parameters of Goats of Semi Arid Environment Fed On Natural Grazing Rangeland of Northern Nigeria
}

\author{
*A. A. Njidda ${ }^{1}$, I. T. Hassan ${ }^{1}$ and E. A. Olatunji ${ }^{2}$ \\ ${ }^{1}$ Department of Animal Science, Bayero University, P.M.B. 3011, Kano State, Nigeria. \\ ${ }^{2}$ Department of Animal Science, University of Abuja, P.M.B. 117, Abuja, Nigeria.
}

\begin{abstract}
The haematological and biochemical parameters of 140 apparently healthy goats consisting of 70 adults ( 35 male and 35 female; 37 buck kids and 33 doe kids) comprised of 3 indigenous and popular breeds of goats of Nothern Nigeria were studied. Data were analysed for the effect of breed, sex and season. Packed cell volume $(P C V)$ was significantly higher $(P<0.05)$ for Kano brown (buck and doe kid) of the north west. Haemoglobin $(\mathrm{Hb})$ values was also higher $(P<0.05)$ for Kano brown adult buck and doe $(P<0.05)$. Red blood cell count $(R B C)$ was significantly higher $(P<0.05)$ for Borno white adult buck and buck kid. The mean corpuscular haemoglobin (MCH) was higher in Kano brown doe (27.3) while the values were much higher in Sokoto red goat kids. The mean corpuscular haemoglobin concentration (MCHC) was significantly higher $(P<0.05)$ for goat kids than in adult goats. The mean corpuscular volume $(M C V)$ was observed to higher for Kano brown buck and buck kid than other breeds of goats. Borno white doe and doe-kid had the highest white blood cell count (WBC). White blood cell differentials shows that lymphocytes was significantly higher $(P<0.05)$ for Borno white goats (adult and kids). Monocytes was only observed in Borno white goats. The serum sodium range from (136.0 to $156.0 \mathrm{mmol} / \mathrm{l})$ for adult goats of all breeds, (132.0 to $160.0 \mathrm{mmol} / \mathrm{l})$ for goat kids of all breeds. Serum potassium range from (6.5 to $9.4 \mathrm{mmol} / \mathrm{l})$ for adult goats, $(4.8$ to $12.3 \mathrm{mmol} / \mathrm{l})$ for goat kids. The chloride, $\mathrm{HCO}^{-3}$ and urea values was higher for adult goats than in kids for all the breeds. Values for creatinine, cholesterol and glucose was observed to be higher for kids than in adult goats. The values for total protein, albumin and globulin showed significant difference $(P<0.05)$ among breeds age and sex. Moreso significant difference $(P<0.05)$ was observed for the enzymes studied in all the breeds of goats of different sexes and ages.
\end{abstract}

Key Words: Haematology, blood chemistry, breeds, goat, kids, buck, doe

\section{Introduction}

Nigeria and especially the southern region have important role in goat production in the Africa continent and the world in general [1]. In this region, the herd is mainly composed of local breed animals without breed type [2] which are characterized by good adaptation to environmental conditions but lower productivity rates when compared to the breeds coming from the temperate regions [3]. Some developing countries as well as Nigeria, with the strategies to meet the increasing demand for animal products, introduced exotic genotype with a high degree of specialization such as white Bornu, Red Sokoto and Anglo- Nubian breeds for example.

The life of all flesh is the blood and its usefulness for assessing the health status, chemical evaluation for survey, physicalogical pathological conditions and diagnostic and prognostic evaluation of various types of diseases in animals cannot be over emphasize $[4,5]$. It also helps in distinguishing normal state form state of stress, which can be maturational, environmental or physical [6] Haematological values are widely used to determine systematic relationship and physiological adaptation including the assessment of general health condition of animal [7]. The changes in these parameters have been studied in cattle [8] sheep [9] and red Sokoto goat [4].

Blood composition of animal might be influenced by certain factors such as nutrition, management, and great of animals, sex, age diseases and stress factors that might affect blood values [10]. The hematological and geochemical indices are an index and reflection of the effects of dietary treatment on the animals in terms of the type and amount of feed ingested and were available for the animals to meet its physiological geochemical and metabolically necessities [11] and also the level of anti-nutritional element of or factors present in the feed also influence the hematological and biochemical values [12]. There is a great variation in the hematological and biochemical parameters as observed between breeds of goats [4, 13] and in this regard, in may be difficult to formulate a universal metabolic profile test for goat [14]. These differences have further underlined the need to establish appropriate physiological baseline values for various breeds of livestock in Nigeria, which could help in the realistic evaluation of the management practice, nutrition and diagnosis of their health condition and 
provide the objective of the study is to evaluate the information on hematological and biochemical data of goat breeds raised under free range system as influenced by breed, sex and age. The data generated will also serve as a guide to the physiological characterization of the breed and helps in interpretation of climatic influence on productivity.

\subsection{Data collection}

\section{Material and Methods}

The most common Nigerian indigenous breeds of goat of semi arid: Kano Brown, Borno White and Sokoto Red goats were used for this study. Blood samples were collected from the jugular vein of 140 goats of different breeds consisting of 70 adults ( 35 bucks and 35 does) and 70 young ones (38 buck-kids and 32 doekids).The live weights of the adult and young goats were $21.5 \pm 0.94$ and $7.5 \pm 0.23(\mathrm{Kg})$ respectively. The goats were bled through jugular vein and $10 \mathrm{ml}$ of blood collected. $3 \mathrm{ml}$ of the blood samples was collected into plastic tube containing EDTA for haematological studies. The remaining $7 \mathrm{ml}$ of blood samples was deposited in anticoagulant free plastic tube and allowed to clot at room temperature within 3 hours of collection. The serum samples were stored at $-20^{\circ} \mathrm{C}$ for biochemical studies. Total erythrocytic counts and total leukocytic counts were determined with the aid of Haemocytometer (Neubaur counting chamber) and $\mathrm{Hb}$ concentration was determined by Sahl's (acid haematin) method [15]. Mean Corpuscular Haemoglobin Concentration (MCHC), Mean Corpuscular Haemoglobin (MCH), Mean Corpuscular Volume (MCV) values were calculated [16]. Serum Aspartate Aminotransferase, serum Alanine Aminotransferase and Alkaline Phosphatase were analyzed spectrophotometric linked reaction method [17]. Other biochemical analysis was done using the method described by Ogunsami et al. [18].

\subsection{Statistical analysis}

Mean values and standard errors were calculated and the results were treated statisticall using student's t-test assessing the mutual statistical differences between adult and young animals [19] and one-way ANOVA was used to assess the statistical difference between male and female.

\subsection{Haematology (Adults)}

\section{Results}

The results of the hematological values for adult goat is shown in table the packed cell volume (PCV) was significantly different $(\mathrm{P}<0.05)$ between breeds with Kano brow buck having the highest $(55.8 \%)$ volume the heaemolobin $(\mathrm{Hb})$ values ranged from $(8.0$ to $11.5 \mathrm{~g} / \mathrm{dl}$ with Borno white also having the highest value $(11.5 \mathrm{~g} / \mathrm{dl})$. The highest value of $16.4 \mathrm{~g} / \mathrm{dl}$ was observed in Borno white buck for red blood cell court (RBC) while Sokoto red buck had the least $(3.03 \mathrm{~g} / \mathrm{dl}) \mathrm{MCH}$ values ranged from 7.48 in Borno white doe to 27.3pg in Kano brown doe. Borno white goats was observed to have the highest mean corpuscular haemoglobin concentration (MCHC) and white blood cell count (WBC) respectively. The lymphocytes values ranged from $35.00 \%$ in Borno while goats to $74.00 \%$ in Kano brown and Sokoto red does. The lymphocyte value for both sex are low (35.00 and 45.00\%) respectively. Borno white buck had the highest neutrophils (57.00\%) followed by does which had $(47.00 \%)$. Eosinophils was observed to be highest $(7.00 \%)$ for Borno white buck followed by Borno white doe (5.00\%). The lowest value was observed in Sokoto red doe (1.00\%). Monocytes was observed only in Borno white goats.

\subsection{Haematology (Kids)}

Kano brown doe-kid had the highest PCV (50.8\%) compared to other breed and sex. Haemoglobin values was observed to be highest in the Kano brown buck and doe kid (12.3 and $12.3 \mathrm{~g} / \mathrm{dl}$ ) respectively. The RBC values ranged from 1.96 for Sokoto red doe kid to $5.0 \mathrm{~g} / \mathrm{dl}$ in Borno white buck-kid. Mean corpuscular haemglobin $(\mathrm{MCH})$ and mean corpuscular haernoglobin concentration $(\mathrm{MCHC})$ was significantly higher for Sokoto red doe kid (39.8 pg and (39.6\%) respectively. Kano brown buck-kid had the highest mean corpuscular value while Brown white doe-kid had the highest value for white blood cell count $\left(33.4 \times 10^{9} \mathrm{~g} / \mathrm{L}\right)$. All the breeds had lymphocytes values above 70\% except for Borno white goat kids which had below 55\%, though the highest value for neutrophils was observed in Borno white buck-kid (63.00\%). Eosinophils values was higher for Borno white doe kid (12.00\%).

\subsection{Biochemical indices (Adults)}

The results of biochemical indices of the adult goats is shown in Table 3. The serum potassium, chloride, creatinine, total protein, and globulin were significantly higher $(\mathrm{P}<0.05)$ in Kano brown buck than any of the breeds and sexes. Values for hydrogencarbonate $\left(\mathrm{HCO}^{-3}\right)$ was observed to be similar statistically $(\mathrm{P}<0.0 .05)$ for Borno white and Sokoto red bucks. Alanine Aminotransferase (ALT) and Alkaline phosphate (ALP) were higher in Sokoto red doe (23.0 and 33.0 IU/L). 


\subsection{Biochemical indices (Kids)}

The result of the biochemical indices for goat-kids is shown in Table 4. Generally all parameters observed showed significant difference $(\mathrm{P}<0.05)$ between breeds and sexes. The value for serum sodium ranged from 132.0 in Sokoto red buck-kid to $160.0 \mathrm{mmol} / \mathrm{l}$ in Kano brown buck-kid. The values for serum potassium was highest in Sokoto red doe-kid $(12.3 \mathrm{mmol} / \mathrm{l})$. Chloride shows higher values $(10.0 \mathrm{mmol} / \mathrm{l})$ for Kano brown than other breeds. Hydrogencarbonate $\left(\mathrm{HCO}^{-3}\right)$ ranged from 18.0 to $20-0 \mathrm{mmlol} / \mathrm{L}$ for all the breeds. Kano brown doe-kid was observed to have the highest value for $(7.2 \mathrm{mmol} / \mathrm{L})$, chloride $(6.6 \mathrm{mmol} / \mathrm{L})$, total protein $(79.0 \mathrm{mmol} / \mathrm{L})$ and globulin $(24.0 \mathrm{mmol} / \mathrm{L})$. All the enzymes observed in this study showed significant difference for $(\mathrm{P}<0.05)$ for all the breeds and sexes.

\section{Discussion}

Packed cell volume (PCV) in this study was higher than $25.7 \pm 3.1 \%$ obtained for Red Sokoto goats [4]. Earlier reports in Baladi goats [13] and Red Sokoto goats [4] showed PCV values of $27.25 \pm 0.59$ and 25.7 \pm 3.1 respectively. The findings of this study support that PCV varies among breeds of goats. Increase in PCV values in this study may be attributing to increase in environmental temperature [20,21]. High PCV haematocrit values indicates either an increase in the number of circulating RBC or reduction in circulating plasma volume [22]. Haematological traits especially PCV and $\mathrm{Hb}$ were correlated with nutritional status of the animal [23]. However, the primary functions of the erythrocyte are to serve as a carrier of haemoglobin. The higher PCV values observe in this study might likely be a sign of healthier goats. Males having higher PCV values than females is a likely hood of inherent sex differences among male and female [24, 25]. Haemoglobin $(\mathrm{Hb})$ concentration in this study fell within the range of high values obtained for Red Sokoto goats [4]. The significant breed and age effect observed in this study may be an indication of productivity and adaptability in relation to the area of research unlike the West African Dwarf (WAD) goats that are highly adapted to the tsetse fly infested areas of the southern forest zone of Nigeria [26]. There was no sex difference observe in this study. The observed difference in adult and young goats suggested that the oxygen carrying capacity of the blood was high in adult goats. The results of the RBC shows that males had higher RBC values than females. The difference due to age and sex is a signal of the health status of the various age groups and sex among the goats breed studied, which is in agreement with the findings of Schalm et al., [10] and Addas et al. [25]. The values of mean corpuscular volume (MCV) significantly increased while MCHC indicate macrocytic and hypochronic anaemia [27], probably due to the increased activity of bone marrow and deficiency of some hemopoietic factors. MCHC is very significant in the diagnosis of anaemia and also serve as a useful index of the capacity of bone marrow to produce red blood cells. Increased MCV may also be observed in regenerative anaemia due to hemolysis and haemorrhages [28, 29]. The higher MCV values indicates macrocytosis [30]. The total White Blood Cell (WBC) count was higher in this study than values obtained for Red Sokoto goats [4], cattle in Nigeria [31] and Nigerian buffaloes [32]. Total WBC counts differentials in adult goats compared well with values obtained for young goats in this study for all the breeds. The higher values obtained in this study suggest well develop immune system of all the breeds of goats. It was reported that, like other ruminants there are more lymphocytes than Neutrophils in circulation [32]. The higher values of the WBC observed may also be attributed to the extensively managed goats which makes them face challenges from microbes when on free range. However, the values obtained in this study fell within the broad range recorded for Red Sokoto goats [4] and WAD goats [14]. The result also reveals non significant effect on age which indicates that the age has little or no effect on the health status of these goat breeds.

The white blood cell differentials (lymphocytes and neutrophils) levels are comparable among the breed, age and sex groups of the animals. In goats like other ruminants there are more lymphocytes than neutrophils in circulation [32]. Lymphocytes are the key elements in the production of immunity. Low levels can be seen in some bacterial infections, aplastic anaemia, and in some forms of leukemia while high values can be observed in viral infections, and in some forms of leukemia [33]. The result in this study is higher than the values (64.8 to 70\%) for adult goats and 67.8 to $55.4 \%$ for goat kids [14], while Tariq Javed et al. [34] reported values ranging from 43.89 to $45.86 \%$ for adult goats respectively. Similarly, increase in lymphocyte percentage has been reported [35]. Depending on the stage and progress of the disease, leukocytosis, leucopoenia, lymphocytosis, lymphopenia, neutrophilia and monocytosis can be observed [36]. There was significant influence of age, sex and breed on lymphocyte count. The value for neutrophils was higher for Borno white goats breeds (adult-kids). Sex influence was also observed for neutrophils with mostly males having the higher values in Kano brown and Borno white breeds. Similar observation was made by Egbe-Nwiyi et al. [24] for goats in arid zone of Nigeria. Neutrophils was observe to be a very effective killing machine [33]. The values for eosinophils in this study was observed to be higher in Borno white goat than the other breeds and the other breeds in this study. The values for males tends to be higher in the adult goats for all the breeds but the doe-kid of Kano brown and Borno white had higher values than buck-kids. Like neutrophils, they release proteins cytokines and chemokines that produce inflammation but are capable of killing invading organism. However, 
the selectins and integrins have some selectivity in the way in which they respond and on the killing molecules they secrete. They are especially abundant in the mucosa of the gastrointestinal tract where they defend against parasites, and in the mucosa of respiratory and urinary tracts [33]. Monocytes generally was not observed in all the breeds except in Borno white goat breed. The values was higher in female (adult goat) and higher in male (buck-kid).

The result of $\mathrm{Na}$ level obtained in this study is high compare to the values (129.3 to $131.0 \mathrm{mmol} / \mathrm{l})$ for adult goats and (138.0 to $138.1 \mathrm{mnnol} / \mathrm{l})$ for kids reported by Bhat et al.[37]. The result of this study is shows that male goats have higher values for $\mathrm{Na}$ than female and there is significant effect on breeds. The young goats (kids) tend to have higher values than the adult goats, there observation was similar to the findings of Bhat et al. [37] Kashimiri goats.

The serum K level was higher in all the breeds studied when compared to the values $(4.3$ to $4.5 \mathrm{mmol} / \mathrm{l})$ for adults and (5.2 to $5.3 \mathrm{mmol} / \mathrm{l})$ for kids reported by Bhat et al. [37] and (7.1mmol/1) for adults goats and 6.8 to $7.8 \mathrm{mmol} / \mathrm{l}$ for kids reported by Opara et al. [14]. The comparison generally reveals that young goats (kids) have higher potassium values than adult goats. The values for chloride show significant variation but are all within close range in terms of sex and age. Kano brown goats tend to have higher values than the other breeds. The result of hydrogen carbonate reveals that there is sex difference with males having higher values than the females. There's little or no difference for breed and age in terms $\mathrm{HCO}^{-3}$.

The urea level in the studied shows that Sokoto red goat (adults) had higher values than the other breeds. The values fro adults goat is higher than the young goats (kids). Generally, the values tends to be higher compares to the values 1.9 to $2.6 \mathrm{mmol} / \mathrm{l}$ (for adult goats) and 1.4 to $3.7 \mathrm{mmol} / \mathrm{l}$ (for goat kids) of WAD goats [38]. The high level of semen urea might be attributed to excessive tissues protein catabolism associated with protein deficiency [39].

Serum creatmine levels were within normal range and differ $(\mathrm{P}<0.05)$ among breeds. The values were higher in the males than females in all breeds and the values tends to be higher in the young goat (kids) than the adults. The result reveal significant effect $(\mathrm{P}<0.05)$ of sex and age difference.

The amount of creatmine secreted daily is a function of the muscle mass and is not affected by diet, age, sex or exercise. It amounts to approximately $2 \%$ of the body stores of creatinine phosphate and is roughly 1-2g/day for adult. Female excrete less creatmine than males because of their smaller muscle mass [40].

Cholesterol values show inconsistency for breed, sex and age. The value shows no significant difference in terms of age. An elevated semen cholesterol concentration has been implicated as one of several risk factors in coronary artery disease, so, the measurement of semen cholesterol concentration is fairly common laboratory procedure [40].

The glucose levels was observed to be higher in young goats (kids) than adults goats. The observed tendency toward decrease in blood glucose and insignificant changeling total protein levels was in agreement with other investigations [41, 42]. The total protein concentration of serum is usually increased in patients with dehydration.

The albumin and globulin values are slightly higher than the value reported by Bhat et al. [37]. Low albumin (hypoalbuminemia) maybe caused by liver disease, nephritic syndrome, burns, protein losing enteropathy, malabsoprtion, malnutrition, late pregnancy, artifact, genetic variations and magnancy. High albumin (hypoalbuminemia) is almost always caused by dehydration. In some cases of retinol (vitamin A) deficiency, the albumin level can become raised to high normal values (ex: $4.9 \mathrm{~g} / \mathrm{dl}$ ). This is because retinol causes cell to swell with water. The result of AST shows the males to the adult and kids have higher values than in females. ALP also follow similar pattern in adult goats but it tends to differ in goat kids with females having the high values of ALT values was observed to be higher in goat kids than adult goats which signify age difference. Generally, the values obtained in this study was higher than the values reported by Opara et al, [14]. West African Diary Goats of South Eastern Nigeria and Bhat et al [37] for Kashimini goats. Serum Aspartate Aminotranmsferase is found in practically every tissue of the body, inducing red blood cell and highly concentrated in candiac muscle and liver, intermediate in skeletal muscle and kidney in much lower concentrations in other tissues. The measurement of the AST levels helpful for the diagnosis and following case of myocardial infarction, hepatocellular disease and skeletal muscle disorders. In trauma or in diseases affecting skeletal muscle, after a renal infarct and in various hemolytic conditions [40]. The concentration of serum Alanine Aminotransferase in tissues is not nearly as great as for serum Aspartate Aminotransferase. If the serum Aspartate Aminotransferase is elevated while the serum Alamin Aminotransferase remains within normal limits in case of suspected myocardial infarction, the results are compatible with myocardial infarction [40].

\section{Conclusion}

Base on this findings, breed, age and sex showed remarkable influence on the haematological and biochemical values of goats studied in semi arid areas of Northern Nigeria. The values obtained are comparable to values recorded elsewhere. There was fluctuation in all the hematological and biochemical parameters of all 
the breeds, sex and age of the animals. What cause the fluctuation in various parameters may be undetected minor infections, weather extremities and poor management in these areas.

\section{References}

[1] Ngere L.O., Adu I.F. and Okunbajo I. O. (1984). The indegenous goats of Nigeria. FAO/UNEP. Animal genetic Resources Information 3:1-9 FAO (Food and Agriculture Organisaton of the United State Nations), Rome, Italy.

[2] Moruppa S.M . and Ngere L.O (1986). Bio metric studies on Bornu white and Red Sokoto (Meradi) goat breeds. Paner presented at the $11^{\text {th }}$ Annual conference of Nigerian society for animal production. Ahmadu Bello University 23-27 March, 1986. Nigeria society for Animal production Ahmadu Bello University Shika-Zaria, Nigeria.

[3] Odo, S.A. Araujo, A.C Santos, A. E Toledo, F.C.P. Yonamine M., Sicva, A.O and lete M.C (2000). indica'oes e limites das ana'lise toxicologicas para substa'ncias psicoativas. Revista de psiquiatria clinica 27:509-56.

[4] Tambuwal F. M, Agale, B. M. and Bangana, A. (2002). Haematological and Biochemicalvalues of Apparently Healthy Red Sokoto goats. Proceedings of $27^{\text {th }}$ Annual conference Nigerian society of Animal production (NSAP) March 17-21, 2002 FOTA, Akure.

[5] Alade, A. A., Bambose, A. M. Ogutona, E.B. and Fanimo, A.O. (2005). Heamatological parameters, serum metabolites carcass characteristic of weaner Rabbits fed yam feel meal diets. Proceedings of $10^{\text {th }}$ annual conference of Animal science Association of Nigeria Dairo, F.A.S. So. K Fajemilehin and G.E Onobi (Eds) held on 12-15 September at university of Ado-Ekiti, Nigeria.pp: $280-282$

[6] Aderemi, F.A (2004). Effects of replacement of wheat bran with cassava root sieviate supplemented of unsupplemented with enzyme on the Haematology and serum biochemistry of pullet chicks. Trop. J. animal Sci. 7:147-153

[7] Kamal Shah M., A. Khan, F. Rizvi, M. Siddique and Sadeeq-ur-rehman. (2007). Effect of cypermethrin on clinicoHaematological parameters in Rabbits. Pauistan vet J. 27(4):171-175.

[8] Ghergariu S, Rowlands, G.J. Pop, N and Moidova, A. (1984). A comparative study of matabolic profiles obtained in Dairy Herds in Romania. British veterinary Journal. 140:600-608

[9] Kausslish, S.K and Arora, K.L. (1977). Studies on Reproduction in sheep. Blood andplasma contents before and after parturition in Nehi sheep. Haryna veterinarian $16(2): 74-\quad 77$.

[10] Schalm O.W, Jain, N. C and Carrol E. J. (1975). Veterinary Haematology. $3^{\text {rd }}$ edition Lea Febiger Philadelphia USA. Pp $13-167$.

[11] Ewuola E.O., Falayan O.A, Cibore, F.A., Adebunmi, A.I Akanji R.A., Ogunlade J.T. and Adeneye J.A (2004). Physiological response of growing west African Dwarf goats fed groundnut shell-based diets as concentrate supplements. BOWEN J. Agric 1 (1): 61-69.

[12] Akinmutimi, A.H (2004). Evaluation of sword bean (Canavalia gladiate) as an alternative feed resources for broiler chickens. phD thesis Micheal Okpara university of Agriculture, Umudike, Nigeria A.O. A.C, 1990 Association of Official Analytical chemists. Methods of Analysis $15^{\text {th }}$ Edition Washington D.C.

[13] Azab, M.E and Abdal-Maksoud, H.A (1999). Changes in some Haematological and biochemical parameters during pre-partum and post-partum periods in female Baladi goats. Small Ruminant Research 34:77-85.

[14] Opara, M.N., Udevi, N. and Okoli I.C (2010). Heamatological parameters and Blood chemistry of Apparently Healthy West African Dwarf (WAD) Goats in Owerri, South Eastern Nigeria. Newyork science Journal 3 (8): 68-72.

[15] Bengamin M.M. (1978). Online of veterinary clinical pathology $2^{\text {nd }}$ edition, Iowa state University Press, Iowa U.S.A pp 35-105.

[16] Jain, N.C. (1986). Haemotological Techniques in: Schalmis veterinary Haematology. Lea and Febiger philadelphia pp:20-86.

[17] Henry, R.J., Chiamori, N., Golub, O.J. and Berkman S. (1960). Revise spectrophotometricmethod for Determination of Glutamic Oxalatic Transaminase and Glutamic Pyruvale Transaminase and lactic and dehydrogenase AM. J. Clinical path 34.381.

[18] Ogunsanmi, O.A, Ozegbe, P.C, Ogunjobi, D., Taiwo, V.O and Adu, J.O. (2002). Haematology plasma Biochemistry and whole blood minerals of the captive Adult African Grasscutter (Thryonomys swinderiamus, Temnick) Trop. Vet., 20(1): $27-35$.

[19] Snedecor G.W and Cochran W.G (1982). Statistical methods, $6^{\text {th }}$ edition Iowa state University Press, 10

[20] Palterson T.B, Shrode R. R., Kunkel H. O, Leghton, R. E. and Rupel I. W. (1960). variation in certain blood components of Holstein and Jersey Cows and their relationship to daily range in rectal temperature and milk and butter fut production journal Dairy Science4. 43:1263-1274.

[21] Isidahomen, E.C, Ikhimioya, I, Njidda A.A and Okoruwa, M. I. (2010). Haematological parameters and Blood chemistry of different species of Ruminant animals in Humid Tropical environment. Nigerian Journal of Agriculture and forestry (NJAF) 3 (1): $85-90$.

[22] Kopp, R and J. Hetesa (2000). Changes of Haemotological studies in adolescent breeding cocks. Acta vet. Brno-69:189-194.

[23] Adejumo, D.O. (2004). Performance, organ development and Haematological of Rats ted sole diets of graded levels of cassava flour and soybean flour (soy gari) as substitutes for energy and protein concentrates. Trop. J. Animal Sci. 7:57-63.

[24] Egbe-Nwiyi, T.N., Nwaosu, S.C and salami, H.A. (2000). Haematological values of apperently Healthy sheep and goats as influenced by age and sen in Arid Zone of Nigeria. Afr. J. Biomed. Res. 3:109-115.

[25] Addas, P. A, A. Midau and D.M Babale (2010). Heamato-biochemical findings of indigenous goats in Mubi Adamawa State Nigeria. J. Agric. Soc. Sci. 6:14-16.

[26] Smith, O.B and M.F.J. Van Houtert (1988). Health aspects of intensive management ofWAD Goats in Humid for est Zone. Bulletin in Animal Health Production in Africa, 36:342-347.

[27] Berger, A.A (2003). The complete blood cell count: A powerful diagnostic tool. Vet. Clin. Small Anim., 33:1207-1222.

[28] Awodi, S.; J.O. Ayo A.D Atodo and T. Dzende (2005). Some Haematological, parameters and the Erythrocyte osmotic fragility in the laughing Dove (Streptopella senegalensis) and the village weaver Bird (Ploceus cucullatus) proceedings $10^{\text {th }}$ Annual conference of Animal science Association of Nigeria Dairo F.A.S., S.O.K. Fajemilehin and G.E. Onibi (Eds) held on 12-15 september at university of Ado Ekiti, Nigeria. Pp:384-387.

[29] Chineke C.A., Olugun, A. G. and Ikeobi, C.O.N. (2006). Haematological parameters in Rabbit Breeds and crosses in Humid Tropic s. Pakistan Journal of Biological sciences 9 (11):2102-2106.

[30] Latimer, K.S., E.A Mahaffey and K.W Prasse (2004). Clinical pathology: veterinary laboratory medicine $4^{\text {th }}$ Ed., Iowa state univ. press Ames, Iowa U.S.A.

[31] Oduye O. O and Fasenimi F. (1971). Serum electrolyte and protein levels in the Nigerian White Fulani and Ndama Breeds of cattle. Bulletin epizootic diseases in Africa 19:333- 339.

[32] Olusanya S.K., Edewor E.E and Health E (1976). Studies on the Blood chemistry andother Haematology parameters in Buffaloes in a Ranch in Nigeria. Nigerian veterinary Journal 5 (1), 27-31.

[33] Ganong W.F. (2005). Review of Medical physilogy. $22^{\text {nd }}$ Edition McGraw-Hill Medical Publication Asias pp 459: $516-532$. 
[34] Tariq Javed M., L Ahmad, M Irfan, I. Ali, A. Khan , M. Wasiq, F.A. Farooqi, A. Latif Shahid and M. Cagiola (2010). Haematological and serum protein values in tuberculin reactor and non-reactor water Buffaloes, Cattle, sheep and Goats pak vet J, 30 (2): 100- 104

[35] Samad M.A, and M.S. Rahman (1986). incidence of borine tuberclosis and its effect on Bangaladash. Indian J Dairy sci, 39:231-234.

[36] Kumar, G.S., PKR. Lyer, MC prass7d and AK Sharma (1994). Tuberclosis in cattle;Haematological studies. Indian J. Vet. Path. 18: $38-42$.

[37] Bhat S.A., Manzoor R. Mir, Sawlehs, Qadir, Allaie, I., H.M. Kham, Ishraq Hussain and S. Bilal (2011). IJAVMS Vols issue, 5:481-487.

[38] Daramola, J.O. A.A. Adeleye, T.A Fatoba and A.O. Soladoye. (2005) Heamatological and biological parameters of west African Dwarf goats. Livestock Res. Rural Dev. 17(8).

[39] Oduye O.O and Adedevon B.K (1976). Bio chemical values of apparently Normal Nigerian sheep. Nigerian veterinary Journal 5 (1):43-50.

[40] Alex, K. and Laverne L.S. (1983). Clinical chemistry; interpretation and Techniques $2^{\text {nd }}$ edition seatle, washington pp:156-339

[41] Yazar, E., Elmas, M., Altunok, V., Sivrikaya A., Oztekin, Birdane Y.O. (2003). Effect of Aminoglycoside antibotics on renal antioxidants, malondialdehyde levels, and some serum biochemical parameters. Can J. vet Res. 67:239-240.

[42] Dinev Toncho, Dimitrinka Zapryanova and lubomir lashew (2007). Changes in some Blood biochemical and Haemotological parameters in goats after Aminoglycoside and Aminocyclitol treatment at therapeutic Doses. Turk. J. vet. Anim Sci 31 (3) 179188.

Table 1: Haematological values of different breeds of goats of Northern Nigeria

\begin{tabular}{|c|c|c|c|c|c|c|}
\hline & \multicolumn{2}{|c|}{ Kano brown } & \multicolumn{2}{|c|}{ Borng, white } & \multicolumn{2}{|c|}{ Sokoto red } \\
\hline & Buck & Doe & Buck & Doe & Buck & Doe \\
\hline PCV $(\%)$ & $55.8 \pm 1.12^{a}$ & $31.0 \pm 0.73^{\circledR}$ & $34.00 \pm 1.2^{d}$ & $38.00 \pm 1.3^{b}$ & $36.1 \pm 2.24^{\circ}$ & $33.1 \pm 0.22^{d}$ \\
\hline $\mathrm{Hb}(\mathrm{g} / \mathrm{dl})$ & $10.7 \pm 0.55^{a}$ & $8.8 \pm 0.44^{c d}$ & $9.0 \pm 0.3^{b c}$ & $11.5 \pm 0.5^{\mathrm{a}}$ & $8.0 \pm 0.29 c d$ & $8.2 \pm 0.34^{c d}$ \\
\hline $\mathrm{RBC}(\mathrm{g} / \mathrm{d} 1)$ & $5.29 \pm 0.12^{c}$ & $3.22 \pm 0.06^{d}$ & $16.4 \pm 1.2^{\mathrm{a}}$ & $14.4 \pm 0.4^{b}$ & $3.03 \pm 0.66^{d}$ & $3.5 \pm 0.23^{d}$ \\
\hline $\mathrm{MCH}(\mathrm{Pg})$ & $20.2 \pm 0.62^{c}$ & $27.3 \pm 0.93^{b}$ & $9.0 \pm 1.1^{d}$ & $7.98 \pm 0.6^{c}$ & $26.4 \pm 1.23^{a}$ & $23.4 \pm 0.67^{\circ}$ \\
\hline $\mathrm{MCHC}(\%)$ & $19.2 \pm 0.09^{f}$ & $28.4 \pm 0.66^{b}$ & $26.47 \pm 2.5^{c}$ & $30.26 \pm 3.1^{\mathrm{a}}$ & $22.2 \pm 1.13^{\circledR}$ & $24.8 \pm 1.3^{d}$ \\
\hline MCV (fl) & $105.5 \pm 2.23^{b}$ & $96.3 \pm 1.23^{\circ}$ & $32.69 \pm 0.7^{d}$ & $26.30 \pm 0.9=$ & $119.1 \pm 3.76^{\mathrm{a}}$ & $94.6 \pm 3.34^{c}$ \\
\hline $\begin{array}{l}\text { WBC } \\
\left(\mathrm{x} 10^{9} / \mathrm{L}\right)\end{array}$ & $18.3 \pm 0.65^{\mathrm{e}}$ & $20.3 \pm 1.33^{d}$ & $13.3 \pm 0.6^{f}$ & $33.4 \pm 0.4^{\mathrm{a}}$ & $24.5 \pm 1.11^{b}$ & $22.0 \pm 1.02^{c}$ \\
\hline \multicolumn{7}{|c|}{ WBC Differencials } \\
\hline $\begin{array}{l}\text { Lymphocytes } \\
(\%)\end{array}$ & $71.0 \pm 2.23^{b}$ & $74.0 \pm 1.08^{a}$ & $35.00 \pm 1.7^{\mathrm{d}}$ & $45.00 \pm 2.2^{c}$ & $71.0 \pm 1.90^{\circ}$ & $74.0 \pm 1.33^{a}$ \\
\hline $\begin{array}{l}\text { Neutrophils } \\
(\%)\end{array}$ & $27.0 \pm 1.71^{\mathrm{c}}$ & $25.0 \pm 1.22^{\mathrm{d}}$ & $57.00 \pm 1.4^{a}$ & $47.00 \pm 2.2^{b}$ & $22.0 \pm 0.33^{\circledR}$ & $25.0 \pm 1.67^{\mathrm{d}}$ \\
\hline $\begin{array}{l}\text { Eosinophils } \\
(\%)\end{array}$ & $2.0 \pm 0.02^{c}$ & $1.0 \pm 0.02^{d}$ & $7.00 \pm 0.2^{a}$ & $5.00 \pm 0.7^{b}$ & $2.0 \pm 0.33^{c}$ & $1.0 \pm 0.02^{d}$ \\
\hline $\begin{array}{l}\text { Monocytes } \\
(\%)\end{array}$ & 0 & 0 & $1 \pm 0.01^{b}$ & $3.00 \pm 0.02^{a}$ & 0 & 0 \\
\hline $\begin{array}{l}\text { Basophils } \\
(\%)\end{array}$ & 0 & 0 & 0 & 0 & 0 & 0 \\
\hline
\end{tabular}

PCV=Packed Cell Volume; $\mathrm{Hb}=$ Haemoglobin; $\mathrm{RBC}=$ Red Blood Cell; WBC $=$ White Blood cells; MCV=Mean corpuscular volume; $\mathrm{MCH}=$ Mean corpuscular haemoglobin; $\mathrm{MCHC}=$ Mean corpuscular haemoglobin Concentration; Means within the same row with different superscripts are significantly different $(\mathrm{P}<0.05)$; NS=Not significant

Table 2: Haematological values of different breeds of goat kids of Northern Nigeria

\begin{tabular}{|c|c|c|c|c|c|c|}
\hline | & \multicolumn{2}{|c|}{ Kano brown } & \multicolumn{2}{|c|}{ Borno white } & \multicolumn{2}{|c|}{ Sokoto red } \\
\hline & Buck kid & Doe kid & Buck kid & Doe kid & Buck kid & Doe kid \\
\hline PCV $(\%)$ & $38 \pm 0.23^{b}$ & $50.8 \pm 0.12^{\mathrm{a}}$ & $36.00 \pm 0.1^{c}$ & $38.00 \pm 0.3^{b}$ & $28.1 \pm 0.17^{d}$ & $19.7 \pm 0.12^{a}$ \\
\hline $\mathrm{Hb}(\mathrm{g} / \mathrm{dl})$ & $12.3 \pm 0.2^{\mathrm{a}}$ & $12.3 \pm 0.04^{\mathrm{a}}$ & $10.1 \pm 0.9^{b}$ & $4.5 \pm 1.2^{d}$ & $9.9 \pm 1.2^{b}$ & $7.8 \pm 0.03^{\circ}$ \\
\hline $\mathrm{RBC}(\mathrm{g} / \mathrm{dl})$ & $3.4 \pm 0.01^{c}$ & $4.9 \pm 0.11^{c}$ & $5.0 \pm 1.6^{a}$ & $4.8 .2 \pm 1.4^{b}$ & $2.56 \pm 0.11^{\mathrm{d}}$ & $1.96 \pm 0.05^{\mathrm{e}}$ \\
\hline $\mathrm{MCH}(\mathrm{Pg})$ & $35.94=0.02^{b}$ & $24 \pm 0.21^{b}$ & $20.20 \pm 0.60^{\mathrm{a}}$ & $22.38 \pm 0.4^{d}$ & $38.7 \pm 1.21^{\mathrm{a}}$ & $39.8 \pm 1.06^{\mathrm{a}}$ \\
\hline $\mathrm{MCHC}(\%)$ & $31.8 \pm 0.12^{c}$ & $24.2 \pm 0.21^{f}$ & $28.05 \pm 0.56^{2}$ & $30.26 \pm 0.7^{d}$ & $35.2 \pm 0.26^{b}$ & $39.6 \pm 0.67^{a}$ \\
\hline MCV (fl) & $112.8 \pm 1.14^{\mathrm{a}}$ & $102.2 \pm 0.14^{c}$ & $72.00 \pm 1.2^{\ddagger}$ & $77.88 \pm 1.4^{\mathrm{d}}$ & $109.8 \pm 0.22^{b}$ & $100.50 \pm 0.66^{c}$ \\
\hline $\begin{array}{l}\text { WBC } \\
\left(\mathrm{x} 10^{9} / \mathrm{L}\right)\end{array}$ & $16.2 \pm 0.26^{d}$ & $19.8 \pm 0.16^{c}$ & $23.3 \pm 0.4^{b}$ & $33.4 \pm 0.8^{\mathrm{a}}$ & $19.8 \pm 1.06^{c}$ & $19.2 \pm 0.33^{c}$ \\
\hline \multicolumn{7}{|c|}{ WBC Differentials } \\
\hline $\begin{array}{l}\text { Lymphocytes } \\
(\%)\end{array}$ & $78.0 \pm 0.06^{b}$ & $81.0 \pm 0.04^{\mathrm{a}}$ & $32.00 \pm 1.2^{d}$ & $51.00 \pm 2.1^{\circ}$ & $81.0 \pm 0.04^{\mathrm{a}}$ & $79 \pm 0.03^{b}$ \\
\hline $\begin{array}{l}\text { Neutrophils } \\
(\%)\end{array}$ & $22.0 \pm 0.03^{c}$ & $18.0 \pm 0.02^{f}$ & $63.00 \pm 1.2^{\mathrm{a}}$ & $36.00 \pm 1.4^{b}$ & $19.0 \pm 0.03^{2}$ & $21.0 \pm 0.02^{\mathrm{d}}$ \\
\hline $\begin{array}{l}\text { Eosinophils } \\
(\%)\end{array}$ & 0 & $02 \pm 0.01^{c}$ & $3.00 \pm 0.4^{b}$ & $12.00 \pm 0.9^{\mathrm{a}}$ & 0 & 0 \\
\hline $\begin{array}{l}\text { Monocytes } \\
(\%)\end{array}$ & 0 & 01 & $2.00 \pm 0.1^{\mathrm{a}}$ & $1.00 \pm 0.02^{b}$ & 0 & 0 \\
\hline $\begin{array}{l}\text { Basophils } \\
(\%)\end{array}$ & 0 & 0 & 0 & 0 & 0 & 0 \\
\hline
\end{tabular}


$\mathrm{PCV}=$ Packed Cell Volume; $\mathrm{Hb}=$ Haemoglobin; RBC=Red Blood Cell; WBC= White Blood cells; $\mathrm{MCV}=$ Mean corpuscular volume; $\mathrm{MCH}=$ Mean corpuscular haemoglobin; $\mathrm{MCHC}=$ Mean corpuscular haemoglobin Concentration; Means within the same row with different superscripts are significantly different $(\mathrm{P}<0.05)$; NS=Not significant

Table 3: Biochemical indices of different breeds of goats of Northern Nigeria

\begin{tabular}{|c|c|c|c|c|c|c|}
\hline & \multicolumn{2}{|c|}{ Kano brown } & \multicolumn{2}{|c|}{ Borno white } & \multicolumn{2}{|c|}{ Sokoto red } \\
\hline & Buck & Doe & Buck & Doe & Buck & Doe \\
\hline $\begin{array}{l}\text { Sodium } \\
(\mathrm{mmol} / \mathrm{L})\end{array}$ & $146 \pm 3.32^{\mathrm{c}}$ & $136.0 \pm 2.78^{\mathrm{e}}$ & $148.0 \pm 2.11^{\mathrm{b}}$ & $140.0 \pm 0.23^{\mathrm{d}}$ & $156.0 \pm 2.22^{\mathrm{a}}$ & $150.0 \pm 2.09^{b}$ \\
\hline $\begin{array}{l}\text { Potassium } \\
(\mathrm{mmol} / \mathrm{L})\end{array}$ & $9.4 \pm 0.56^{\mathrm{a}}$ & $6.5 \pm 0.06^{\mathrm{d}}$ & $9.3 \pm 0.56^{\mathrm{a}}$ & $7.3 \pm 0.04^{\mathrm{c}}$ & $9.0 \pm 0.02^{\mathrm{a}}$ & $8.3 \pm 0.07^{\mathrm{ab}}$ \\
\hline $\begin{array}{l}\text { Chloride } \\
\text { (mmol/L) }\end{array}$ & $108 \pm 2.33^{\mathrm{a}}$ & $106.0 \pm 3.32^{\mathrm{ab}}$ & $107.0 \pm 2.98^{\mathrm{a}}$ & $106.0 \pm 3.33^{\mathrm{ab}}$ & $106.0 \pm 3.21^{\mathrm{ab}}$ & $108.0 \pm 1.56^{\mathrm{a}}$ \\
\hline $\begin{array}{l}\mathrm{HCO}^{-3} \\
(\mathrm{mmol} / \mathrm{L})\end{array}$ & $22 \pm 0.88^{\mathrm{ab}}$ & $21.0 \pm-.92^{\mathrm{bc}}$ & $23.0 \pm 1.06^{\mathrm{a}}$ & $20.0 \pm 0.45^{\mathrm{cd}}$ & $24.0 \pm 0.67^{\mathrm{a}}$ & $22.0 \pm 0.09^{\mathrm{ab}}$ \\
\hline $\begin{array}{l}\text { Urea } \\
(\mathrm{mmol} / \mathrm{L})\end{array}$ & $5.6 \pm 0.03^{c}$ & $7.3 \pm 0.04^{b}$ & $7.7 \pm 0.22^{b}$ & $7.1 \pm 0.09^{b}$ & $8.5 \pm 0.01^{\mathrm{a}}$ & $8.1 \pm 0.02^{\mathrm{a}}$ \\
\hline $\begin{array}{l}\text { Creatinine } \\
(\mathrm{mmol} / \mathrm{L})\end{array}$ & $91 \pm 0.96^{\mathrm{a}}$ & $30.0 \pm 1.08^{\mathrm{e}}$ & $62.0 \pm 0.56^{b}$ & $51.0 \pm 0.98^{\mathrm{c}}$ & $53.0 \pm 0.33^{\mathrm{c}}$ & $42.0 \pm 1.29^{\mathrm{d}}$ \\
\hline $\begin{array}{l}\text { Cholesterol } \\
(\mathrm{mmol} / \mathrm{L})\end{array}$ & $2.9 \pm 0.02^{\mathrm{c}}$ & $4.4 \pm 0.22^{\mathrm{a}}$ & $4.4 \pm 0.9^{\mathrm{a}}$ & $3.2 \pm 0.2^{b}$ & $3.1 \pm 0.27^{b}$ & $4.3 \pm 0.08^{\mathrm{a}}$ \\
\hline $\begin{array}{l}\text { Glucose } \\
(\mathrm{mmol} / \mathrm{L})\end{array}$ & $1.94 \pm 0.01^{b}$ & $2.50 \pm 0.02^{\mathrm{a}}$ & $1.6 \pm 0.2^{b}$ & $1.9 \pm 0.6^{6}$ & $1.66 \pm 0.01^{b}$ & $1.66 \pm 0.02^{b}$ \\
\hline $\begin{array}{l}\text { Total } \\
\text { protein } \\
(\mathrm{g} / \mathrm{L})\end{array}$ & $84.0 \pm 0.59^{\mathrm{a}}$ & $84.0 \pm 0.33^{\mathrm{a}}$ & $47 \pm 1.2^{\mathrm{d}}$ & $74.00 \pm 1.3^{b}$ & $69.0 \pm 1.33^{\mathrm{c}}$ & $84.0 \pm 1.33^{\mathrm{a}}$ \\
\hline $\begin{array}{l}\text { Albumin } \\
(\mathrm{mmol} / \mathrm{L})\end{array}$ & $31.0 \pm 0.22^{\mathrm{a}}$ & $31.0 \pm 0.55^{\mathrm{a}}$ & $31 \pm 1.4^{\mathrm{a}}$ & $26.00 \pm 1.1^{\mathrm{c}}$ & $31.0 \pm 0.93^{\mathrm{a}}$ & $29.0 \pm 0.06^{b}$ \\
\hline $\begin{array}{l}\text { Globulin } \\
(\mathrm{mmol} / \mathrm{L})\end{array}$ & $58.0 \pm 0.33^{\mathrm{a}}$ & $53.0 \pm 1.06^{\mathrm{c}}$ & $16 \pm 0.9^{f}$ & $48.00 \pm 1.3^{\mathrm{d}}$ & $38.0 \pm 1.65^{\mathrm{e}}$ & $55.0 \pm 1.22^{\mathrm{b}}$ \\
\hline $\begin{array}{l}\text { AST } \\
\text { (IU/L) }\end{array}$ & $58.0 \pm 0.23^{b}$ & $84.0 \pm 1.07^{\mathrm{a}}$ & $53.0 \pm 1.01^{d}$ & $56.11 \pm 0.03^{\mathrm{c}}$ & $52.0 \pm 0.94^{\mathrm{e}}$ & $52.0 \pm 1.11^{\mathrm{e}}$ \\
\hline $\begin{array}{l}\text { ALT } \\
\text { (IU/L) }\end{array}$ & $22.0 \pm 0.12^{b}$ & $19.0 \pm 0.23^{\mathrm{d}}$ & $21.0 \pm 0.66^{\mathrm{c}}$ & $22.0 \pm 1.42^{b}$ & $9.0 \pm 0.04^{\mathrm{d}}$ & $23.0 \pm 1.02^{\mathrm{a}}$ \\
\hline $\begin{array}{l}\text { ALP } \\
\text { (IU/L) }\end{array}$ & $42.0 \pm 1.01^{\mathrm{f}}$ & $86.0 \pm 0.55^{b}$ & $51.0 \pm 0.22^{\mathrm{e}}$ & $72.0 \pm 1.78^{\mathrm{c}}$ & $56.0 \pm 1.06^{\mathrm{d}}$ & $133.0 \pm 2.96^{\mathrm{a}}$ \\
\hline
\end{tabular}

AST=Aspartate Aminotransferase; ALT $=$ Alanine Aminotransferase; ALP= Alkaline Phosphatase; Means within the same row with different superscripts are significantly different $(\mathrm{P}<0.05)$; NS=Not significant

Table 4: Biochemical indices of different breeds of goat kids of Northern Nigeria

\begin{tabular}{|l|c|c|c|c|c|c|}
\hline & \multicolumn{2}{|c|}{ Kano brown } & \multicolumn{2}{c|}{ Borno white } & \multicolumn{2}{c|}{ Sokoto red } \\
\hline & Buck kid & Doe kid & Buck kid & Doe kid & Buck kid & Doe kid \\
\hline $\begin{array}{l}\text { Sodium } \\
(\mathrm{mmol} / \mathrm{L})\end{array}$ & $160.0 \pm 2.23^{\mathrm{a}}$ & $150.0 \pm 2.14^{\mathrm{c}}$ & $147.0 \pm 1.2^{\mathrm{d}}$ & $156 \pm 1.06^{\mathrm{b}}$ & $132.0 \pm 1.23^{\mathrm{e}}$ & $146 \pm 1.54^{\mathrm{d}}$ \\
\hline $\begin{array}{l}\text { Potassium } \\
(\mathrm{mmol} / \mathrm{L})\end{array}$ & $6.0 \pm 0.05^{\mathrm{c}}$ & $6.4 \pm 0.11^{\mathrm{c}}$ & $7.2 \pm 0.12^{\mathrm{b}}$ & $6.3 \pm 0.71^{\mathrm{c}}$ & $4.8 \pm 0.34^{\mathrm{d}}$ & $12.3 \pm 0.41^{\mathrm{a}}$ \\
\hline $\begin{array}{l}\text { Chloride } \\
(\mathrm{mmol} / \mathrm{L})\end{array}$ & $110.0 \pm 3.22^{\mathrm{a}}$ & $110.0 \pm 0.25^{\mathrm{a}}$ & $105.0 \pm 0.55^{\mathrm{d}}$ & $106.0 \pm 0.22^{\mathrm{c}}$ & $106 \pm 2.33^{\mathrm{c}}$ & $108 \pm 1.23^{\mathrm{b}}$ \\
\hline $\begin{array}{l}\mathrm{HCO}{ }^{-3} \\
(\mathrm{mmol} / \mathrm{L})\end{array}$ & $20.0 \pm 1.06^{\mathrm{a}}$ & $18.0 \pm 0.56^{\mathrm{b}}$ & $20.0 \pm 0.04^{\mathrm{a}}$ & $18.0 \pm 0.11^{\mathrm{b}}$ & $18.0 \pm 0.92^{\mathrm{b}}$ & $20.0 \pm 0.81^{\mathrm{a}}$ \\
\hline $\begin{array}{l}\text { Urea } \\
(\mathrm{mmol} / \mathrm{L})\end{array}$ & $6.1 \pm 0.11^{\mathrm{b}}$ & $7.2 \pm 0.04^{\mathrm{a}}$ & $7.2 \pm 0.44^{\mathrm{a}}$ & $6.3 \pm 0.11^{\mathrm{b}}$ & $7.4 \pm 0.03^{\mathrm{a}}$ & $6.5 \pm 0.08^{\mathrm{b}}$ \\
\hline $\begin{array}{l}\text { Creatinine } \\
(\mathrm{mmol} / \mathrm{L})\end{array}$ & $136.0 \pm 2.73^{\mathrm{b}}$ & $63.0 \pm 0.93^{\mathrm{d}}$ & $176.0 \pm 1.23^{\mathrm{a}}$ & $86.0 \pm 1.33^{\mathrm{c}}$ & $54.0 \pm 1.06^{\mathrm{f}}$ & $60.0 \pm 1.33^{\mathrm{e}}$ \\
\hline $\begin{array}{l}\text { Cholesterol } \\
(\mathrm{mmol} / \mathrm{L})\end{array}$ & $3.7 \pm 0.03^{\mathrm{c}}$ & $6.6 \pm 0.06^{\mathrm{a}}$ & $4.1 \pm 0.7^{\mathrm{b}}$ & $3.30 \pm 0.6^{\mathrm{c}}$ & $5.7 \pm 0.19^{\mathrm{a}}$ & $3.3 \pm 0.89^{\mathrm{c}}$ \\
\hline Glucose & $2.78 \pm 0.02^{\mathrm{b}}$ & $2.74 \pm 0.52^{\mathrm{b}}$ & $2.3 \pm 0.1^{\mathrm{b}}$ & $2.70 \pm 0.1^{\mathrm{b}}$ & $1.94 \pm 0.66^{\mathrm{c}}$ & $3.6 \pm 0.23^{\mathrm{a}}$ \\
\hline
\end{tabular}


Haematological and biochemical parameters of goats of semi arid environment fed on natural

\begin{tabular}{|l|l|l|l|l|l|l|}
\hline$(\mathrm{mmol} / \mathrm{L})$ & & & & & & \\
\hline $\begin{array}{l}\text { Total } \\
\text { protein } \\
(\mathrm{mmol} / \mathrm{L})\end{array}$ & $69.0 \pm 0.09^{\mathrm{d}}$ & $79.0 \pm 1.06^{\mathrm{a}}$ & $62.00 \pm 2.4^{\mathrm{c}}$ & $67.00 \pm 2.6^{\mathrm{e}}$ & $73.0 \pm 2.11^{\mathrm{b}}$ & $71.0 \pm 2.06^{\mathrm{c}}$ \\
\hline $\begin{array}{l}\text { Albumin } \\
(\mathrm{mmol} / \mathrm{L})\end{array}$ & $31.0 \pm 0.83^{\mathrm{b}}$ & $31.0 \pm 0.56^{\mathrm{b}}$ & $38.00 \pm 1.3^{\mathrm{a}}$ & $38.00 \pm 1.3^{\mathrm{a}}$ & $31.0 \pm 0.65^{\mathrm{b}}$ & $29.0 \pm 0.28^{\mathrm{c}}$ \\
\hline $\begin{array}{l}\text { Globulin } \\
(\mathrm{mmol} / \mathrm{L})\end{array}$ & $38.0 \pm 0.45^{\mathrm{c}}$ & $48.0 \pm 0.57^{\mathrm{a}}$ & $24 \pm 1.1^{\mathrm{e}}$ & $29.00 \pm 1.2^{\mathrm{d}}$ & $42.0 \pm 1.42^{\mathrm{b}}$ & $42.0 \pm 1.23^{\mathrm{b}}$ \\
\hline $\begin{array}{l}\text { AST } \\
(\mathrm{lU} / \mathrm{L})\end{array}$ & $109.0 \pm 2.98^{\mathrm{a}}$ & $58.0 \pm 1.02^{\mathrm{e}}$ & $108.0 \pm 0.22^{\mathrm{b}}$ & $59.0 \pm 0.32^{\mathrm{d}}$ & $107.0 \pm 3.04^{\mathrm{c}}$ & $58.0 \pm 0.62^{\mathrm{e}}$ \\
\hline $\begin{array}{l}\text { ALT } \\
(\mathrm{lU} / \mathrm{L})\end{array}$ & $24.0 \pm 0.08^{\mathrm{d}}$ & $25.0 \pm 1.10^{\mathrm{c}}$ & $29.0 \pm 0.04^{\mathrm{a}}$ & $26.0 \pm 0.06^{\mathrm{b}}$ & $24.0 \pm 0.33^{\mathrm{d}}$ & $25.0 \pm 101^{\mathrm{c}}$ \\
\hline $\begin{array}{l}\text { ALP } \\
(\mathrm{lU} / \mathrm{L})\end{array}$ & $77.0 \pm 1.07^{\mathrm{f}}$ & $107.0 \pm 1.33^{\mathrm{c}}$ & $82.0 \pm 0.08^{\mathrm{e}}$ & $113.0 \pm 0.6^{\mathrm{a}}$ & $83.0 \pm 2.32^{\mathrm{d}}$ & $110.0 \pm 3.22^{\mathrm{b}}$ \\
\hline
\end{tabular}

AST=Aspartate Aminotransferase; ALT = Alanine Aminotransferase;ALP = Alkaline Phosphatase; Means within the same row with different superscripts are significantly different $(\mathrm{P}<0.05)$; NS=Not significant 